Свешникова Таисия Константиновна

магистрант

ФГБОУ ВО «Московский педагогический государственный университет»

г. Москва

Катханова Юлия Федоровна д-р пед. наук, профессор Институт изящных искусств ФГБОУ ВО «Московский педагогический государственный университет» г. Москва

DOI $10.31483 / r-32732$

\title{
ЭЛЕКТРОННЫЕ ОБРАЗОВАТЕЛЬНЫЕ РЕСУРСЫ В ОБУЧЕНИИ ЦВЕТОВЕДЕНИЮ
}

Аннотация: в статье рассмотрены вопросы оформления и содержательного наполнения современных обучающих электронных образовательных ресурсов, перечислены преимущцества и отрицательные факторы относительно использования этих ресурсов в процессе обучения. Преимущчества и минимизацию негативных влияний электронных ресурсов в современном образовательном пространстве рассматривает дисииплина «Педагогический дизайн», предлагая инструменты, необходимые для разработки результативных, привлекательных и понятных для обучающиххя иүифровых учебных материалов. В статье перечисляются основные дидактические задачи электронных ресурсов, а также примерные составляющие компоненты циифрового ресурса «Цветоведение» для будущчих художников-педагогов.

Ключевые слова: электронный образовательный ресурс, педагогический дизайн, интерактивность, визуализация информации.

Электронные образовательные ресурсы (ЭОР) в настоящее время стали инновационными ресурсами повышения эффективности образовательного 
пространства, инструментами решения развивающих педагогических задач. Под ЭОР в данном случае мы понимаем дидактические материалы, представленные в цифровом виде. Исследователи неоднократно отмечали необходимость внедрения цифровых технологий в процесс образования. Так, Ю.Ф. Катханова обращает внимание на то, что «обучение с использованием цифровых технологий позволяет реализовать многие дидактические принципы, например, наглядность, представленная в аудио-, фото-, видео-, которая активизирует внимание обучающихся, усиливает их восприятие учебной информации, повышает эмоциональный фон, мотивацию к учению, формирует способы познания мира, собственной деятельности, развивая научный стиль мышления и творческие способности» [4, с. 123]. «Использование цифровых технологий в обучении активизирует мыслительную деятельность обучающихся за счет представления различной визуальной информации, переработки этой информации в соответствии с целями и задачами обучения» [4, с. 122].

К преимуществам ЭОР можно отнести высокую вариативность, мобильность, интерактивность, мультимедийность, моделинг, учет уровня подготовленности обучающихся. Т.С. Северова отмечает, что вариативность образовательных ресурсов, которая связана с возможностью учащихся самостоятельно выбирать и комбинировать образовательные модули. Причем мобильность носителей и предоставление возможности самостоятельного выбора времени и места получения образовательных услуг делают ЭОР комфортными для пользователя. Интерактивность электронного образовательного ресурса заключается в возможности взаимодействия пользователя с программой и последующем получении соответствующего отклика. И.Ф. Исаев и А.Г. Клепикова считают, что «интерактивность в обучении означает выполнение какой-либо деятельности в соответствии с новой информацией, мотивируя обучающихся, во-первых, к самостоятельному принятию решений; во-вторых, к взаимодействию с другими в информационно-образовательной среде; в-третьих, к выбору средств обучения» [3, с. 130]. Моделинг электронного образовательного ресурса предполагает представление объекта действительности в графическом или мультимедийном 
формате и предполагает определенную зависимость свойств и качеств моделируемого объекта от тех или иных задаваемых условий. Мультимедийность электронного образовательного ресурса состоит в полиформности средств передачи контента. «Современные электронные ресурсы по определению должны иметь опору на наглядное мультимедиа, основанное на стерео- и 3D-контенте и выверенный интерактив дидактически «умной» программы. Причем они могут быть доступными в онлайн на любом компьютере, планшете или смартфоне, в любой OS, а также иметь SCORM-версии для погружения в LMS-систему любого учебного заведения» [4, с. 131].

При неоднократном акцентировании положительных сторон, тем не менее, использование электронных образовательных ресурсов может быть сопряжено с рядом недостатков. К ним можно отнести: факторы, присущие самим устройствам (низкая мобильность, требования к наличию адекватного оборудования и навыкам работы с ним, ошибки и нарушения в проектировании конкретных устройств); факторы, связанные с разработкой электронного учебного пособия (недостаточность или перенасыщению учебного материала научными сведениями); факторы, связанные с процессом обучения (чрезмерная нагрузка, несоответствие учебного материала возрастным особенностям, отсутствие личного контакта между учеником и учителем) [1].

Решением задач достижения преимуществ и минимизации негативных влияний ЭОР в учебном процессе занимается учебная дисциплина, как «Педагогический дизайн». Широко интерпретируемое понятие «Педагогический дизайн» «...выполняет свою миссию формообразования в новом поведенческом, визуальном, цифровом формате, нацеленную на конструирование и внедрение формул преобразования: формирует понятие о международной привлекательности учебного заведения, контролирует норматив информационной эстетики, имиджевой стратегии учебного заведения, артистичность проведения занятий, постоянный поиск более презентабельных форм позиционирования научных достижений педагогов и студентов» [5, с. 35]. 
Педагогический дизайн трактуется также как приведенные в систему знания, используемые в процессе учебной работы, проектировании и оценки эффективности разработанных учебных материалов [6]. Педагогический дизайн ЭОР объединяет в себе два вектора работы. С одной стороны, он решает задачи дизайна, а с другой - опирается на классические педагогические принципы. К основным задачам, находящимся в поле работы педагогического дизайнера, относят:

- определение целевой аудитории;

- выявление формируемых компетенций обучающихся;

- предполагаемые результаты обучения;

- структуру учебных материалов;

- средства обучения;

- используемые методы обучения;

- методы оценки;

- композиционный стиль и оформление материала;

- методические рекомендации разработчикам;

- оценку эффективности образовательного ресурса.

В нашем случае ЭОР в обучении будущего художника-педагога цветоведению также должен соответствовать перечисленным дидактическим задачам. Отсюда возникает необходимость уточнения содержания такого ресурса и его составляющие компоненты:

- теоретическая основа цветоведения;

- визуальные средства поддержки практических заданий;

- методические рекомендации по выполнению практических заданий;

- контролирующие средства обучения;

- дополнительные источники в виде ссылок и списка литературы.

При этом обучение цветоведению должно быть направлено на:

- развитие умений обучающихся видеть и воспринимать красоту разнообразных и выразительных цветовых отношений предметов;

- понимание эстетической и эмоциональной стороны цвета; 
- изучение символики цвета в различных культурах;

- приведение цветовых отношений в гармонию и гармонические сочетания цвета [2].

Очевидно, что эффективность ЭОР зависит не только от структуры и информационного наполнения содержания, но и от эффективности визуализации представленной информации, которая во многом зависит от соблюдения следующих дидактических принципов: целесообразности и единства изучаемого материала; его доминанты; целостного соподчинения; динамизма; равновесия; гармонии; пропорциональности; последовательности и акцента.

Анализ проведенного исследования позволил сделать вывод о том, что грамотный и содержательно наполненный электронный образовательный ресурс по цветоведению можно разработать при условии использования классических дидактических принципов и ориентиров, соответствующих составляющим компонентам педагогического дизайна и отвечающих основным требованиям к визуализации представляемой информации вне зависимости от цели и задач любой учебной дисциплины.

\section{Список литературы}

1. Балаева Е.Ю. Дидактические риски использования электронных средств обучения // Непрерывное образование: XXI век. - 2016. - №4 (16). - С. 3-10.

2. Долгих Н.Н. Колористика в дизайн-образовании // Вестник Томского государственного педагогического университета. - 2016. - №8 (173). - С. 57-63.

3. Исаев И.Ф. Технология педагогического дизайна в разработке электронных учебных материалов / И.Ф. Исаев, А.Г. Клепикова // Вестник Тамбовского университета. Серия: Гуманитарные науки. - 2009. - №1 (69). - С. 130-135.

4. Катханова Ю.Ф. Творческие способности и их развитие в графической деятельности: монография. - Чебоксары: ИД «Среда», 2018. - 140 с.

5. Сергеева Е.А. Роль педагогического дизайна в создании электронных образовательных ресурсов // Научно-технический вестник информационных технологий, механики и оптики. - 2006. - №32. - С. 296-297. 
6. Уваров А.Ю. Педагогический дизайн // Информатика. - 2003. №30 (415). - 102 c. 